Research Journal of Applied Sciences, Engineering and Technology 5(10): 3044-3051, 2013

DOI:10.19026/rjaset.5.4621

ISSN: 2040-7459; e-ISSN: 2040-7467

(C) 2013 Maxwell Scientific Publication Corp.

Submitted: September 27, $2012 \quad$ Accepted: November 13, 2012

Published: March 25, 2013

\title{
Research Article \\ Long and Short Run Relationship Analysis of Monetary and Fiscal Policy on Economic Growth in Nigeria: A VEC Model Approach
}

\author{
Y. Musa and B.K. Asare \\ Department of Mathematics (Statistics), Usmanu Danfodiyo University, Sokoto
}

\begin{abstract}
This study investigates and measures the long and short run relationship of monetary and fiscal policies on economic growth in Nigeria. A Vector Error Correction (VEC) models technique was employed to analyse and draw policy inferences. Through the VEC model, the relationships then have been investigated by the long-run relationships in the cointegrating vector and the short-run effects from the VEC model. From the cointegration analysis, the long-run relationships give some possible indications of growth in Nigerian economy. We find that the Nigerian economy is determined mostly by money supply. It is clear also from the findings those monetary policy variables: money supply and minimum rediscount rate have dominant long-run effects on the economy. From these results it is clear that monetary policy exacted greater impact on the economic growth but the effects of fiscal policy had lower magnitude more specifically when there is decrease in the inflation rate. Additionally, the $35 \%$ speed of adjustment to the short run disequilibrium shows an improvement in the Nigeria economic growth. Although, both monetary and fiscal policy variables may contribute to economic growth in the short and long term, but based on these findings monetary policy will exact more impact if it facilitates the supply side of the economy through money supply.
\end{abstract}

Keywords: Long run, short run, VEC model

\section{INTRODUCTION}

The achievement of macroeconomic goals namely full employment, stability of price level, high and sustainable economic growth and external balance, has been a policy priority of every economy whether developed or developing given the susceptibility of macroeconomic variables to fluctuations in the economy. The realization of these goals undoubtedly is not automatic but requires policy guidance. This policy guidance represents the objective of economic policy. Fiscal and monetary policy instruments are the main instruments of achieving the macroeconomic targets.

Fiscal and monetary policies are the tools through which an economy is regulated by the government or the respective central bank. The objectives of monetary and fiscal policies in Nigeria are wide-ranging. These include increase in Gross Domestic Product (GDP) growth rate, reduction in the rates of inflation and unemployment, improvement in the balance of payments, accumulation of financial savings and external reserves as well as stability in Naira exchange rate (CBN, 2009). Generally, both fiscal and monetary policies seek at achieving relative macroeconomic stability.

The relative impact of fiscal and monetary policy has been studied extensively in many literatures.
Friedman and Meiselman (1963), Ansari (1996), Reynolds (2000), Chari et al. (1991), Shapiro and Watson (1988), Blachard and Quah (1989) and Clarida and Gali (1994). Chari and Kehoe (1998), Chowdhury (1988), Weeks (1999), Chowdhury et al. (1986), Feldstein (2002) and Cardia (1991) have examined the impact of fiscal and monetary policies on various aggregates.

However, the bulk of theoretical and empirical research has not reached a conclusion concerning the relative power of fiscal and monetary policy to effect economic growth. Some researchers find support for the monetarist view, which suggests that monetary policy generally has a greater impact on economic growth and dominates fiscal policy in terms of its impact on investment and growth (Ajayi, 1974; Elliot, 1975; Batten and Hafer, 1983), while other argued that fiscal stimulates are crucial for economic growth (Chowdhury et al., 1986; Olaloye and Ikhide, 1995). However Cardia (1991) found that monetary policy and fiscal policy play only a small role in varying investment, consumption and output.

Montiel (1989) applied a five-variable VAR model (money, wages, exchange rate, income and prices) to examine sources of inflationary shocks in Argentina, Brazil and Israel. The findings indicate that exchange rate movements among other factors significantly 
explained inflation in the three countries. Other studies which have reached similar conclusions are Kamin (1996), Odedokun (1996), Elbadawl (1990), Nnanna (2002) and Lu and Zhang (2003).

Suleman et al. (2009) in their study of money supply, government expenditure, output and prices in Pakistan found that government expenditure and inflation are negatively related to economic growth in the long run while money supply (M2) positively, impact on economic growth.

Morley (1992) analyzed the effect of real exchange rates on output for twenty eight devaluation experiences in developing countries using a regression framework. After the introduction of controls for factors that could simultaneously induce devaluation and reduce output including terms of trade, import growth, the money supply and the fiscal balance, he observed that depreciation of the level of the real exchange rate reduced the output.

Since coordination among the stabilization policies can be fruitful in the progress of an economy that is facing dual challenges of growth and price stability, one of the objectives of the underlying study is to examine Nigeria's economy by investigating the policy responses to and their effects on, all the endogenous variables.

Despite their demonstrated efficacy in other economies as policies that exert influence on economic activities, both policies have not been sufficiently or adequately used in Nigeria (Ajisafe and Folorunso, 2002). However, few studies have applied the VAR approach on studies of Inflation and output growth in Africa countries, including Nigeria (Ajisafe and Folorunso, 2002).

In Nigeria, there have been very few empirical studies regarding the relative efficacy of the stabilization tools. Okpara (1988) in his study on money supply, government expenditure and prices in Nigeria, found a very poor and insignificant relationship between government expenditure and prices.

Olubusoye and Oyaromade (2008) analyzing the source of fluctuations in inflation in Nigeria using the frame work of error correction mechanism found that the lagged Consumer Price Index (CPI) among other variables propagate the dynamics of inflationary process in Nigeria. The level of output was found to be insignificant but the lagged value of money supply was found to be negative and significant only at the $10 \%$ level in the parsimonious error correction model.

Omoke and Ugwuanyi (2010) in their long run study of money, price and output in Nigeria found no contegrating vector but however found that money supply granger causes both output and inflation suggesting that monetary stability can contribute towards price stability.

Oluwole and Olugbenga (2007) in their study of M2 Targeting, Money Demand and Real GDP Growth in Nigeria: Do Rules Apply? Showed that the CBN was not strongly committed to its annual M2 money growth targets, but more importantly, the deviations from M2 target growth rates impacted real GDP growth rate and inflation rate adversely during the period.

Ajisafe and Folorunso, (2002), in their analysis, they shows that monetary rather than fiscal policy exerts a great impact on economic activity in Nigeria using cointegration and error correction modeling techniques. The emphasis on fiscal action of the government has led to greater distortion in the Nigerian economy.

The main aim of this research study is to empirically estimate and measure the long run and short run dynamic relationship that exist between the monetary and fiscal policy and the economic growth in Nigeria using Vector Error Correction Model (VECM) from 1970 to 2010, similar to that of Ajisafe and Folorunso, (2002).

The rest of the study is organized as follows; the next section presents some macroeconomic indicators performance. Section 3; Data and Econometric Methodology. Results and discussion are presented in section 4 . The last section concludes the study.

\section{MATERIALS AND METHODS}

Description of data: The data sets used for this analysis is the annual series of the selected relevant macroeconomic variables from 1970 to 2010 . The data for money supply (broad money M2), exchange rate and Minimum rediscount rate will be used as monetary policy variables. Data for government revenues both oil and non-oil revenues, government expenditure (capital and recurrent) will be used as fiscal policy variables. Data for gross domestic product (both Agriculture and industrial) and Inflation rate (proxy by consumer price index) will be used as non-policy or growth variables. The data were obtained from Central Bank of Nigeria, Statistical Bulletin 2009 and 2010.

Model specification: Sims's (1980) seminal work introduces unrestricted Vector Auto Regressions (VARs) that allows feedback and dynamic interrelationship across all the variables in the system and appears to be highly competitive with the largescale macro-econometric models in forecasting and policy analysis.

To provide an empirical insight into the effectiveness of monetary and fiscal policy on prices and economic growth in Nigeria, we estimates sevenvariable VAR model by using LGDP, LCPI, LMSP, EXG, MRR, LREV and LEXPT, to analyze the response of two policy variables to economic variables. Following Habibur (2005) in Bangladesh and Amarasekara (2006) in Sri Lanka we formulate the model:

$$
\begin{aligned}
& \mathrm{LGDP}_{\mathrm{t}}=\alpha_{0}+\alpha_{1} \mathrm{LCPI}_{\mathrm{t}}+\alpha_{2} \mathrm{LMSP}_{\mathrm{t}}+\alpha_{3} \\
& \mathrm{EXG}_{\mathrm{t}}+\alpha_{4} \mathrm{MRR}_{\mathrm{t}}+\alpha_{5} \mathrm{LREV}+\alpha_{6} \mathrm{LEXPT}+\mu_{\mathrm{t}}
\end{aligned}
$$


where, $a_{0}$ is the constant and $\alpha_{1}, \alpha_{2}, \alpha_{3}, \alpha_{4}, \alpha_{5}, \alpha_{6}$ are coefficient to be estimated and $\mu_{\mathrm{t}}$ is an error term. LGDP is the natural log of real Gross domestic product, LCPI is the natural log of consumer price index, LMSP is the natural log of Money supply (M2), EXG is the Real official exchange rate, MRR is the Minimum rediscount rate, LREV is the natural $\log$ of Government oil and non-oil revenues, LEXPT is the natural log of Government expenditure.

The variables GDP, CPI, MSP, REV and EXPT are incorporated into the model in their natural logs while EXG and MRR remain in their original form. This is to enable us index all the variables and to aid interpretation of results. Lutkephl and Kratzig (2004), reveal that constructing a model for the logs is likely to be advantageous because the changes in the log series display a more stable variance than the changes in the original series.

The General basic model of VAR $(p)$ has the following form:

$$
y_{t}=\mu+\psi D_{t}+A_{1} y_{t-1}+\ldots+A_{p} y_{t-p}+u_{t}
$$

where, $\mathrm{y}_{\mathrm{t}}$ is the set of $\mathrm{K}$ time series variables $\mathrm{y}_{\mathrm{t}}=$ $\left(\mathrm{y}_{1 \mathrm{t}}, \ldots, \mathrm{y}_{\mathrm{Kt}}\right)^{\prime}, \mathrm{A}_{\mathrm{I}}^{\prime}$ are $(\mathrm{K} \times \mathrm{K})$ coefficient matrices, $\mu$ is vector of deterministic terms, $D_{t}$ is a vector of nonstochastic variables such as economic intervention and seasonal dummies and $\mu_{\mathrm{t}}=\left(\mu_{1 \mathrm{t}}, \ldots, \mu_{\mathrm{Kt}}\right)^{\prime}$ is an unobservable error term. Although the model (2) is general enough to accommodate variables with stochastic trends, it is not the most suitable type of model if interest centers on the cointegration relations. The VECM form:

$\Delta y_{t}=\Pi y_{t-1}+\Gamma_{1} \Delta y_{t-1}+\ldots+\Gamma_{p-1} \Delta y_{t-p+1}+\mu+\psi D_{t}+u_{t}$

where, $\Pi=\alpha \beta$

In the VECM model, attention focuses on the $(n \times$ $r$ ) matrix of cointegrating vectors $\beta$, which quantify the "long-run" relationships between variables in the system and the $(n \times r)$ matrix of error-correction adjustment coefficients $\alpha$, which load deviations from the equilibrium (i.e. , , $\prod y_{t-1}$ ) to $\Delta \mathrm{y}_{\mathrm{t}}$ for correction. The $\Gamma_{i}$ coefficients in (3) estimate the short-run effects of shocks on $\Delta \mathrm{y}_{\mathrm{t}}$, and therefore allow the short-run and long-run responses to differ.

The term , $\prod y_{t-1}$ is the only one that includes I (1) variables. Hence, $\prod y_{t-1}$ must also be I (0). Thus, it contains the cointegrating relations. The $\prod y_{j s}(j=1, \ldots$ $., p-1)$ are often referred to as the short-run or shortterm parameters and $\prod y_{t-1}$ is sometimes called the long-run or long-term part.

Unit root test: Since we are using times series data sets for the analysis, it is important that we first test the data sets for stationarity properties. Hence, to examine the stationarity properties of the data sets, we use a variety of units root tests. The motivation behind the assortment of tests is to obtain reliable and consistent results.

First, the Augmented Dickey Fuller (ADF) tests and Phillips-Perron (PP) tests are used to check whether each data series is integrated and has a unit root. The $\mathrm{ADF}$ test is based on the following regressions.

$$
\begin{aligned}
& \Delta y_{t}=a_{0}+a_{1} y_{t-1}+\sum_{i=1}^{n} a_{1} \Delta y_{i}+e_{t} \lambda_{i} \\
& \Delta y_{t}=a_{0}+a_{1} y_{t-1}+\sum_{i=1}^{n} a_{1} \Delta y_{i}+\delta_{t}+e_{t}
\end{aligned}
$$

where,

$y_{t} \quad=$ A time series

$t=$ A linear time trend

$\Delta \quad=$ The first difference operator

$\alpha_{0}=$ A constant

$n \quad=$ The optimum number of lags on the dependent variable

$e_{t} \quad=$ The random error term

The difference between Eq. (4) and (5) is that the first equation includes just drift. However, the second equation includes both drift and linear time trend. This study also employs the Philip-Perron test due to Phillip and Perron (1988). Since the possibility of the presence of structural breaks makes the ADF test unreliable for testing stationarity. The presence of a structural break will tend to bias the ADF test towards non-rejection of the null hypothesis of a unit root. The regression equation for the PP test is given by:

$$
\Delta Y_{t}=\alpha+b Y_{t-1}+\varepsilon_{t}
$$

Thus, in addition to the traditional tests of DickeyFuller and Phillips-Perron, we also employ the Kwiatkowski, Phillips, Schmidt and Shin"s (KPSS) test designed to overcome the problems of low power and size distortions inherent in the traditional tests (Maddala and Kim, 1998)

VAR cointegration test: The results of the integration tests are then pursued by Co-integration tests. The Existence of long-run equilibrium (stationary) relationships among economic variables is referred to in the literature as cointegration. The Johansen procedure will be employed to examine the question of cointegration and provide not only an estimation methodology but also explicit procedures for testing for the number of cointegrating vectors as well as for restrictions suggested by economic theory in a multivariate setting. Engle and Granger (1987) pointed out that a linear combination of two or more nonstationary variables may be stationary. If such a stationary combination exists, then the non-stationary time series are said to be co-integrated. The VAR based 
co-integration test using the methodology developed in Johansen (1991, 1995). Johansen's methodology takes its starting point in the vector auto regression (VAR) of order $\mathrm{p}$ given by:

$$
y_{t}=\mu+\Delta_{1} y_{t-1}+\ldots+\Delta_{p} y_{t-p}+\varepsilon_{t}
$$

where, $y_{t}$ is an $\mathrm{nx} 1$ vector of variables that are integrated of order commonly denoted (I (1)) and $\varepsilon_{t}$ is an $\mathrm{nx} 1$ vector of innovations. This VAR can be rewritten as:

$$
\Delta y_{t}=\mu+\Pi y_{t-1}+\Gamma_{1} \Delta y_{t-1}+\ldots+\Gamma_{p-1} \Delta y_{t-p+1}+\varepsilon_{t}
$$

where,

$$
\begin{aligned}
& \Pi=-\left(I_{n}-A_{1}-\ldots-A_{p}\right) \Gamma_{\mathrm{i}} \\
& =-\left(\mathrm{A}_{\mathrm{i}+1}+\ldots+\mathrm{A}_{\mathrm{p}}\right)
\end{aligned}
$$

and To determine the number of co-integration vectors, Johansen (1988) and Johansen and Juselius (1990) suggested two statistic tests, the first one is the trace test ( $\lambda$ trace). It tests the null hypothesis that the number of distinct cointegrating vector is less than or equal to $n$ against a general unrestricted alternatives $n=r$. the test calculated as follows:

$$
\lambda_{\text {trace }}(r)=-T \sum_{r+1}^{n} \ln \left(1-\hat{\lambda}_{i}\right)
$$

where, $\mathrm{T}=$ The number of usable observations and the $\hat{\lambda}_{i}$ are the estimated eigenvalue from the matrix. The Second statistical test is the maximum eigenvalue test ( $\lambda$ max) that is calculated according to the following formula:

$$
\lambda_{\text {max }}(r, r+1)=-T \ln \left(1-\hat{\lambda}_{r+1}\right)
$$

The test concerns a test of the null hypothesis that there is $\mathrm{r}$ of co-integrating vectors against the alternative that $r+1$ co-integrating vector.

\section{RESULTS AND DISCUSSION}

Unit root tests: The unit root test, such as Augmented Dickey-Fuller (Dickey and Fuller, 1981), PhillipsPerron (Phillip and Perron, 1988) and KwiatkowskiPhillips-Schmidt-Shin (Kwiatkowski et al., 1992) tests are used to determine the order of integration for each series. The tests are performed using 95\% simulated critical value as developed by Pesaran and Pesaran (2009) in Microfit 5.0, the results of which are summarized in Table 1. For ADF, DL-GLS and PP test the null hypothesis of non-stationary is rejected if the tstatistic is less than the critical t-value while the KPSS

\begin{tabular}{|c|c|c|c|c|c|c|c|c|}
\hline \multirow[b]{2}{*}{ Variables } & \multicolumn{4}{|l|}{ Constant } & \multicolumn{4}{|c|}{ Constant and trend } \\
\hline & $\begin{array}{l}\text { ADF } \\
\text { t-statistic }\end{array}$ & $\begin{array}{l}\text { DF-GLS } \\
\text { t. statistic }\end{array}$ & $\begin{array}{l}\text { PP } \\
\text { t. statistic }\end{array}$ & $\begin{array}{l}\text { KPSS } \\
\text { t. statistic }\end{array}$ & $\begin{array}{l}\text { ADF } \\
\text { t-statistic }\end{array}$ & $\begin{array}{l}\text { DF-GLS } \\
\text { t. statistic }\end{array}$ & $\begin{array}{l}\text { PP } \\
\text { t. statistic }\end{array}$ & $\begin{array}{l}\text { KPSS } \\
\text { t. } \\
\text { statistic }\end{array}$ \\
\hline$\overline{\text { LGDP }}$ & -2.4854 & -0.30028 & -3.5159 & 1.2162 & -2.3271 & -1.7281 & -1.8836 & 0.29354 \\
\hline LCPI & -0.82440 & 0.23910 & -0.45534 & 1.4512 & -1.5709 & -1.7386 & -1.6742 & 0.15303 \\
\hline LMSP & -0.49969 & 0.038484 & 0.33034 & 1.4472 & -2.7591 & -2.7878 & -1.5130 & 0.15458 \\
\hline EXG & 0.43604 & 0.46241 & 0.71245 & 1.1733 & -1.5281 & -1.3344 & -1.3037 & 0.31213 \\
\hline MRR & -1.5924 & -1.3096 & -1.9601 & 0.76601 & -0.91515 & -1.3385 & -1.7985 & 0.28013 \\
\hline LREV & -0.73161 & 1.0493 & -1.0587 & 1.4432 & -2.0029 & -2.0726 & -2.3502 & 0.14210 \\
\hline LEXPT & -0.79676 & 1.0201 & -0.68676 & 1.4471 & -1.9211 & -1.9557 & -2.1814 & 0.11590 \\
\hline \multicolumn{5}{|c|}{ Simulated critical values (5\%) } & \multicolumn{4}{|c|}{ Simulated critical values $(5 \%)$} \\
\hline \multicolumn{5}{|c|}{$\mathrm{ADF}=-2.9582$} & \multicolumn{4}{|c|}{$\mathrm{ADF}=-3.4873$} \\
\hline \multicolumn{5}{|c|}{ DF-GLS $=-2.3522$} & \multicolumn{4}{|c|}{ DF-GLS $=-3.2248$} \\
\hline \multicolumn{5}{|c|}{$\mathrm{PP}=-2.9607$} & \multicolumn{4}{|c|}{$\mathrm{PP}=-3.4523$} \\
\hline \multicolumn{5}{|c|}{ KPSS $=0.43882$} & \multicolumn{4}{|c|}{$\mathrm{KPSS}=0.14165$} \\
\hline
\end{tabular}
test the null hypothesis is stationary.

Note that the ADF, DL-GLS and PP tests are based on the null of unit -root while KPSS test assumes the null of stationarity. Using The ADF, DL-GLS and PP

Table 1: ADF, DF-GLS, PP \& KPSS test using simulated critical values

*Critical value $=95 \%$ simulated critical value using 1000 replications; $*$ the critical values are computed by stochastic simulations

Table 2: Cointegration test (Linear deterministic trend); Lags interval (in first differences): 1 to 1 Unrestricted Cointegration rank test (trace)

\begin{tabular}{lccc} 
Hypothesized No of CE (s) & Eigenvalue & Trace statistic & 0.05 Critical value \\
\hline None $*$ & 0.701125 & 138.1911 & 125.6154 \\
At most 1 & 0.591261 & 91.08966 & 95.75366 \\
At most 2 & 0.475142 & 56.19721 & 69.81889 \\
At most 3 & 0.233437 & 31.05675 & 47.85613 \\
At most 4 & 0.213733 & 20.68907 & 29.79707 \\
At most 5 & 0.153078 & 11.31116 & 15.49471 \\
At most 6 & 0.116517 & 4.831426 & 3.841466 \\
Trace test indicates 1 cointegrating eqn (s) at the 0.05 level; * denotes rejection of the hypothesis at the & 0.05 level; **MacKinnon-Haug-
\end{tabular}


Res. J. Appl. Sci. Eng. Technol., 5(10): 3044-3051, 2013

Table 3: Cointegration test (Linear deterministic trend); Lags interval (in first differences): 1 to 1

Unrestricted cointegration rank test (maximum eigenvalue)

\begin{tabular}{|c|c|c|c|c|}
\hline ypothesized No. of CE(s) & Eigenvalue & Max-eigenstatistic & 0.05 Critical value & Prob.** \\
\hline None* & 0.701125 & 47.10148 & 46.23142 & 0.0403 \\
\hline At most 1 & 0.591261 & 34.89245 & 40.07757 & 0.1711 \\
\hline At most 2 & 0.475142 & 25.14047 & 33.87687 & 0.3756 \\
\hline At most 3 & 0.233437 & 10.36767 & 27.58434 & 0.9791 \\
\hline At most 4 & 0.213733 & 9.377908 & 21.13162 & 0.8008 \\
\hline At most 5 & 0.153078 & 6.479739 & 14.26460 & 0.5524 \\
\hline At most $6 *$ & 0.116517 & 4.831426 & 3.841466 & 0.0279 \\
\hline
\end{tabular}

Max-eigenvalue test indicates 1 cointegrating eqn (s) at the 0.05 level; * denotes rejection of the hypothesis at the 0.05 level; **MacKinnonHaug-Michelis (1999) p-values

Table 4: VAR granger causality/block erogeneity Wald tests

\begin{tabular}{lllll}
\hline Dependent variable & Excluded variable & Chi-squared & Degrees of freedom & p-values \\
\hline LGDP & LCPI & 0.953230 & 2 & 0.6209 \\
LGDP & LMSP & 2.072655 & 2 & 0.3548 \\
LGDP & EXG & 1.036149 & 2 & 0.5957 \\
LGDP & MRR & 0.312796 & 2 & 0.8552 \\
LGDP & LREV & 0.479219 & 2 & 0.7869 \\
LGDP & LEXPT & 1.782283 & 2 & 0.4102 \\
LGDP & LCPI,LMSP,EXG,MRR,LREV,LEXPT & 6.226134 & 12 & 0.9043 \\
\hline
\end{tabular}

tests, all other variables possess unit roots at their levels since each reported t-statistics is not smaller than their respective critical values. The KPSS tests in the other hand also reject the null hypothesis of stationarity for all the variables at their levels, which is in line with the estimated results from ADF, DL-GLS and PP tests.

Cointegration test: A major requirement in conducting Johansen and Juselius (1992) Johansen (1995) cointegration tests and estimation of a VAR system, either in its unrestricted or restricted Vector Error Correction (VEC) forms, is the choice of an optimal lag length. Lag length were selected using information criteria and the best lag length are found to be two that meet the mathematical stability condition.

The unit root tests confirmed that the series are integrated thus satisfying the initial assumption for cointegration analysis.

The results of the maximal eigenvalue and trace test statistics for the two models were presented in Table 2 and 3 . The p-values at 5\% and 10\% level of significant indicate that the hypothesis of no cointegration among the variables can be rejected for Nigeria. Both Trace test and Maximum Eigenvalue test found one cointegrating relationships at 5\% significant level between the economic, monetary and fiscal policy variables in Nigeria.

Since the variables are cointegrated, thus, it is concluded that there exists a long-run equilibrium relationship between economic growth variables and members of monetary-fiscal series.

Block Erogeneity Wald tests for beta restrictions: Variables were included in the following order: Gross Domestic Product (LGDP), Consumer Price Index (LCPI), Money supply (LMSP), Exchange rate (EXG), Minimum Rediscount Rate (MRR), Government Revenue (LREV) and Government Expenditure (LEXPT) for Block Exogeneity Wald test.
Table 5: Wald test for beta restrictions (consumer price index)

\begin{tabular}{lll}
\hline Restriction & $\beta(2,1)=1$ & $\beta(2,1)=-1$ \\
\hline Test statistic & 2.5639 & 1.6670 \\
p-value & 0.1093 & 0.1967 \\
Degree of freedom & 1.0000 & 1.0000 \\
\hline
\end{tabular}

Block Exogeneity Wald test statistically determine which variables can be exogenous in a cointegrated VAR system. A necessary condition for exogeneity of a variable is that current and past values of other variables do not affect this variable. Table 4 below summarises the Block Exogeneity Wald test by Enders (1995).

The null hypotheses of the block Exogeneity Wald tests in Table 4 is that the excluded variable(s) does(do) not Granger cause the dependent variable.These hypotheses would be rejected if the calculated p-values were less than 0.05 , at the 5.0percent or 0.1 , at 10 percent level of significances. Given the finding that the LGDP series was not Granger caused by any other variable and that these other variables did not jointly Granger cause real GDP, this variable real GDP was taken as an exogenous variable in the equilibrium relationship.

According to Enders' (1995) illustrations of the Johansen (1988) procedure for cointegration, this finding can be used to impose a long-run relationship so that the equilibrium coefficients are normalised using the LGDP coefficient. The block Exogeneity tests confirmed that the economic justifications for the selection of variables were appropriate.

Table 5 is the test for beta restrictions of consumer price index. The null hypothesis that these restrictions are insignificant can be rejected. This will allow us to imposed beta restriction on the coefficient of consumer price index.

Long term and short term parameter estimates: Long term parameter $(\beta)$ estimates and the error correction term obtained from the cointegrated VAR analysis, are shown in Table 6 and 7. These long term 
Res. J. Appl. Sci. Eng. Technol., 5(10): 3044-3051, 2013

Table 6: Long-run coefficient of the cointegrating vector (beta)

\begin{tabular}{lll}
\hline & Cointegration restriction $\beta(2,1)=1$ & Cointegration restriction $\beta(2,1)=1$ \\
\hline LGDP(-1) & Coint Eq. (1). & Coint Eq1 \\
LCPI(-1) & $1.000(0.000)\{0.000\}[0.000]$ & $1.000(0.000)\{0.000\}[0.000]$ \\
LMSP(-1) & $1.000(0.000)\{0.000\}[0.000]$ & $-1.000(0.000)\{0.000\}[0.000]$ \\
EXG(-1) & $-2.067(0.267)\{0.000\}[-7.752]$ & $-1.861(0.253)\{0.000\}[-7.341]$ \\
MRR(-1) & $0.011(0.004)\{0.004\}[2.847]$ & $0.006(0.004)\{0.124\}[1.537]$ \\
LREV(-1) & $-0.136(0.024)\{0.000\}[-5.701]$ & $-0.093(0.023)\{0.000\}[-4.118]$ \\
LEXPT(-1) & $0.643(0.543)\{0.236\}[1.184]$ & $1.329(0.516)\{0.010\}[2.574]$ \\
\end{tabular}

Table 7: Loading coefficients (alpha)

\begin{tabular}{|c|c|c|c|c|c|c|c|}
\hline \multirow[b]{2}{*}{ Error correction } & \multicolumn{7}{|c|}{ Speed of adjustment (short -run equilibrium) } \\
\hline & D(LGDP) & $\mathrm{D}$ (LCPI) & D(LMSP) & $\mathrm{D}(\mathrm{EXG})$ & $\mathrm{D}(\mathrm{MRR})$ & $\mathrm{D}$ (LREV) & $\mathrm{D}($ LEXPT $)$ \\
\hline CointEq1 & $\begin{array}{c}-0.345 \\
(0.144) \\
\{0.017\} \\
{[-2.393]}\end{array}$ & $\begin{array}{c}-0.018 \\
(0.054) \\
\{0.740\} \\
{[-0.332]}\end{array}$ & $\begin{array}{c}-0.016 \\
(0.054) \\
\{0.761\} \\
{[-0.304]}\end{array}$ & $\begin{array}{c}-3.704 \\
(4.652) \\
\{0.426\} \\
{[-0.796]}\end{array}$ & $\begin{array}{l}1.927 \\
(1.247) \\
\{0.122\} \\
{[1.545]}\end{array}$ & $\begin{array}{c}-0.062 \\
(0.118) \\
\{0.600\} \\
{[-0.524]}\end{array}$ & $\begin{array}{c}-0.078 \\
(0.101) \\
\{0.438\} \\
{[-0.775]}\end{array}$ \\
\hline
\end{tabular}

Values in () std. Dev., \{\} p-values, [] t-value

Table 8: VEC model residual test

Portmanteau test $(\mathrm{H} 0: \mathrm{Rh}=(\mathrm{r} 1, \ldots, \mathrm{rh})=0)$

test statistic

p-value

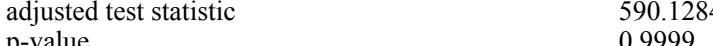

$\begin{array}{ll}\text { degrees of freedom } & 721.000\end{array}$

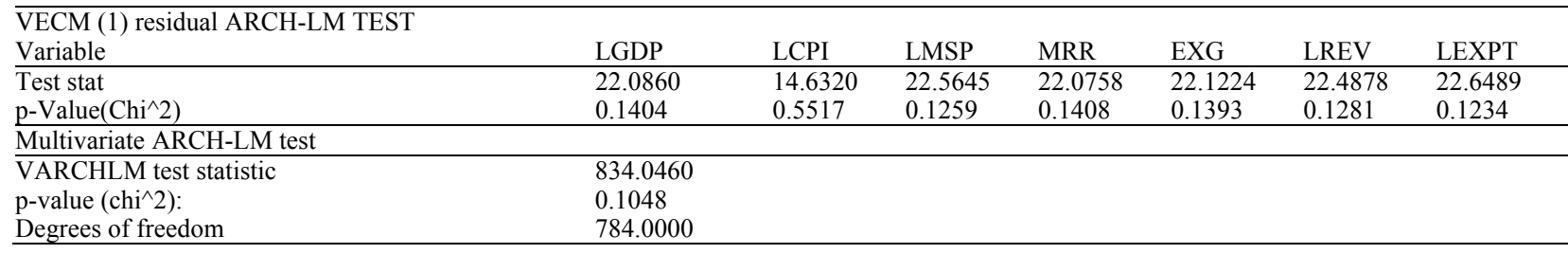

estimates and the short term error correction coefficients $(\alpha)$ are components of the $\Pi$ matrix, where, $\Pi=\alpha \beta$. The short term parameters, including the error correction coefficients, represent the dynamic adjustment processes in the specification.

The long-run relationships: We have these long-run relationships as follows:

$$
\begin{aligned}
& \text { LGDP }=-1 * \text { LCPI }+2.067 * \text { LMSP } \\
& 0.011 * \mathrm{EXG}+0.128 * \mathrm{MRR} 0 . .643 * \mathrm{LREV}+0.025 * \mathrm{LE} \\
& \mathrm{XPT} \\
& \mathrm{LGDP}=1 * \mathrm{LCPI}+1.861 * \mathrm{LMSP}-0.006 * \mathrm{EXG} \\
& +0.093 * \mathrm{MRR}-1.329 * \mathrm{LREW}-0.941 * \mathrm{LEXP}
\end{aligned}
$$

The conclusions that we can extract from these long-run relationships give some possible indications of the answers to the issues posed in our introduction especially those related to the long run impact of monetary and fiscal policy on economic growth in Nigeria.

Normalizing variable LGDP, the long-run cointegration relationship is presented in Eq. (11) and (12).

In Eq. (11), if there is decrease of inflation by $1.0 \%$, then, the estimated long term coefficient for money supply showed that for every 1.0 percent increase in money supply there will be growth of about $2.01 \%$ of real GDP and is found to statistical significant. The money supply variable induces a more than proportionate change on real GDP. Minimum rediscount rate and official exchange rate estimates were found to have positive and negative significant contributions to real GDP respectively. For every 1.0 percent growth in Minimum rediscount rate, GDP grew by 0.13 percent. This finding implies that Nigeria should from time to time make a reasonable increase in the minimum rediscount rate and while doing it precaution should be putting into consideration. Official exchange rate was found to reduce real GDP by 0.01 percent for every $1.0 \%$ depreciation in exchange rate. This finding suggest that in Nigeria, if there is depreciation of Naira against the US Dollar, there is possibility that import will increase and dependant on foreign goods will certainly increase. Government revenue and expenditure showed negative and positive effects on real GDP respectively. But the impacts are statistically insignificant.

It is clear from Eq. (12) that, if inflation increases by $1.0 \%$ then, the growths of money supply and minimum rediscount rate have dominant long-run effects on real GDP than exchange rate, revenues and expenditure. For instance, a 1 percent increase in minimum rediscount rate will increase real GDP by 0.09 percent and the contribution is significant, while 
exchange rate, government revenues and expenditure have significant negative effect to the real output if prices continue to rise.

The speed of adjustment coefficient (Table 7) is correctly signed and statistically significant in the cointegration equation. Following short run disequilibrium in real GDP, error correction coefficients show that the average adjustment is $35 \%$ in the cointegration equation. Therefore, the $35 \%$ adjustment to the short run disequilibrium shows a tendency of improvement the Nigerian economic growth.

VECM residual tests: In Table 8 , the residuals of VECM (1) are tested for portmanteau test for Autocorrelation, Residual ARCH-LM TEST and Multivariate ARCH-LM TEST. The joint test for null hypothesis of no autocorrelation cannot be rejected at the all conventional level, the residuals do not suffered from Autocorrelation problem. We can observe that there is no ARCH in the residual of individual variables base on the Residual ARCH-LM test and no ARCH in the system equation based the Multivariate ARCH-LM test.

\section{CONCLUSION AND POLICY IMPLICATION}

We evaluated the long run and short run dynamic relationship of the Nigerian economy in a VEC Model system with estimating on monetary policy, fiscal policy and economic growth variables.

The estimated long term coefficient for money supply showed that for every 1.0 percent increase in money supply there will be growth of about $2.01 \%$ of real GDP and is found to statistical significant, if there is decrease of inflation by $1.0 \%$. The money supply variable induces a more than proportionate change on real GDP. Minimum rediscount rate and official exchange rate estimates were found to have positive and negative significant contributions to real GDP respectively. This finding suggest that in Nigeria, depreciation of Naira against the US Dollar, means there is possibility that import will increase and dependant on foreign goods will certainly increase. Government revenue and expenditure showed negative and positive effects on real GDP respectively. But the impacts are statistically insignificant. It is clear, if inflation increases by $1.0 \%$ then, the growths of money supply and minimum rediscount rate have dominant long-run effects on real GDP than exchange rate, revenues and expenditure. Following short run disequilibrium in real GDP, error correction coefficients show that the average adjustment is 35\% in the cointegration equation. Therefore, the $35 \%$ adjustment to the short run disequilibrium shows a tendency of improvement in the Nigerian economic growth.

Both monetary and fiscal variables are generally used as a tool for economic stabilization and for long and short term demand management. Although, both monetary and fiscal policy variables may contribute to economic growth in the long term, but based on these findings monetary policy will exact more impact if it facilitates the supply side of the economy through money supply( similar results can found in Ajisafe and folorunso, 2002).

\section{REFERENCES}

Ajayi, S.I., 1974. The demand for money in the Nigerian economy: Comments and extensions. Niger. J. Econ. Soc. Stud., 16(1): 165-173.

Ajisafe, R.A. and B.A. Folorunso, 2002. Relative effectiveness of fiscal and monetary policy in macroeconomic management in Nigeria. Afr. Econ. Bus. Rev., 3(1).

Amarasekara, C., 2006. The impact of monetary policy on economic growth and inflation in Sri Lanka. Staff Stud., 38(1, 2).

Ansari, M.I., 1996. Monetary vs. fiscal policy: Some evidence from vector auto regressions for India. J. Asian Econ., 2: 677-687.

Batten, D.S. and R.W. Hafer, 1983. The relative impacts of monetary and fiscal actions on economic activity: A cross-country comparison. Fed.Reserve Bank St., 65(5-12).

Blachard, O. and D. Quah, 1989. The dynamic effects of aggregate supply and demand shocks. Am. Econ. Rev., 79(4).

Cardia, E., 1991. The dynamics of a small open economy in response to monetary, fiscal and productivity shocks. J. Monetary Econ., pp: 41134.

CBN (Central Bank of Nigeria), 2009. Annual Economic Report. Abuja.

Central Bank of Nigeria, Statistical Bulletin, 2009.

Central Bank of Nigeria, Statistical Bulletin, 2010.

Chari, V. and P.J. Kehoe, 1998. Optimal fiscal and monetary policy. Staff Report 251, Federal Reserve Bank of Minneapolis.

Chari, V.V., L. Christiano and J.P. Kehoe, 1991. Optimal fiscal and monetary policy: Some recent results. J. Money Credit Bank, 23: 519-539.

Chowdhury, A., 1988. Monetary policy, fiscal policy and aggregate economic activity: Some further evidence. Appl. Econ., pp: 63-71.

Chowdhury, A., J. Fackler and W. McMillin, 1986. Monetary policy, fiscal policy and investment spending: An empirical analysis. South. Econ. J., pp: 794-805.

Clarida, R. and J. Gali, 1994. Sources of real exchangerate fluctuations: How important are nominal shocks? Carnegie-Rochester Conference Series on Public Policy, 41: 1-56.

Dickey, D.A. and W.A. Fuller, 1981. Likelihood ratio statistics for autoregressive time series with a unit root. Econometrica, 49(4): 1057-1072. 
Enders, W., 1995. Applied Econometric Time Series. Wiley, New York.

Engle, R.F. and C.W.F. Granger, 1987. Cointegration and error correction: Representation and testing. Econometrica, 55: 251-276.

Elbadawl, I.A., 1990. Inflationary Process, Stabilization and the Role of Public Expenditure in Uganda. World Bank, Washington, DC.

Elliot, J.W., 1975. The influence of monetary and fiscal actions on total spending: The St. Louis total spending equation revisited. J. Money Credit Bank, 7: 181-192.

Feldstein, M., 2002. The Role for Discretionary Fiscal Policy in a Low Interest Rate Environment. NBER Working Paper 9203, National Bureau of Economic Research, Cambridge.

Friedman, M. and D. Meiselman, 1963. The Relative Stability of Monetary Velocity and the Investment Multiplier in the United States, 1887-1957. In Stabilization Policies, Prentice Hall, Englewood.

Habibur, R., 2005. Relative Effectiveness of Monetary and Fiscal Policies on Output Growth in Bangladesh: A VAR Approach. Policy Analysis Unit (PAU) Research Department, Bangladesh Bank.

Johansen, S., 1988. Statistical analysis of co-integrating vectors. J. Econ. Dyn. Control, 12(June-Sept): 231-54.

Johansen, S., 1991. Estimation and hypothesis testing of cointegration vectors in Gaussian vector autoregressive models. Econometrica, 59: 1551-1581.

Johansen, S., 1995. Likelihood based Inference in Cointegrated Vector Autoregressive Models. Oxford University Press, Oxford.

Johansen, S. and K. Juselius, 1990. Maximum likelihood estimation and inference on cointegration with applications to the demand for money. Oxford B. Econ. Stat., 52(2): 169-210.

Johansen, S. and K. Juselius 1992. Testing structural hypothesis in a multivariate co-integration analysis of the PPP and the UIP for UK. J. Econometrics, 53: 211-244.

Kamin, S.B., 1996. Exchange Rates and Inflation in Exchange Rate Based Stabilization: An Empirical Examination. International Finance Discussion Paper, No. 554, Federal Reserve Board, Washington, D.C.

Kwiatkowski, D., P.C.B. Phillips, P. Schmidt and Y. Shin, 1992. Testing the null of stationary against the alternative of a unit root: How sure are we that the economic time series have a unit root? J. Econometrics, 54: 159-178.

Lu, M. and Z. Zhang 2003. Exchange rate reform and its inflationary consequences: An empirical analysis for China. Appl. Econ., 35(2): 189-199.

Lutkephl, H. and M. Kratzig, 2004. Applied Time Series Econometrics. Cambridge University Press, New York.
Maddala, G.S. and K. In-Moo, 1998. Unit Roots, Cointegration and Structural Change. Cambridge University Press, Cambridge.

Morley, S.A., 1992. On the effect of devaluation during stabilization programs in LDCs. Rev. Econ. Stat., 74(1): 21-27.

Montiel, P., 1989. Empirical analysis of high inflation episodes in Argentina, Brazil and Israel. IMF Staff Papers, 36(3): 527-49.

Nnanna, O.J., 2002. Monetary Policy and Exchange Rate Stability in Nigeria. Nigerian Economic Society, Ibadan.

Odedokun, M.O., 1996. Dynamics of Inflation in SubSaharan Africa: The Role of Foreign Inflation, Official and Parallel Market Exchange Rates and Monetary Growth. University of Dundee, Dundee, Scotland.

Okpara, G.C., 1988. Government expenditure, money supply and prices in Nigeria (1970:87): An econometric analysis. M.Sc. Thesis, Department of Economics, University of Jos.

Olaloye, A.O. and S.I. Ikhide, 1995. Economic sustainability and the role of fiscal and monetary policies in a depressed economy: The case study of Nigeria. J. Sustain. Dev., 3: 89-100.

Olubusoye, O.E. and R. Oyaromade, 2008. Modelling the Inflation Process in Nigeria. African Economic Research Consortium, AERC Research Paper 182, Nairobi, pp: 1-36.

Oluwole, O. and A.O. Olugbenga, 2007. M2 targeting, money demand and real GDP growth in Nigeria: Do rules apply? J. Bus. Pub. Aff., 1(2).

Omoke, P.C. and C.U. Ugwuanyi, 2010. Money price and output: Causality test for Nigeria. Am. J. Sci. Res., 8: 78-87.

Pesaran, B. and M.H. Pesaran, 2009. MICROFIT 5.0 Windows Commercial Single User Upgrade + Manual. Oxford University Press, pp: 624.

Phillip, P.C.B. and P. Perron, 1988. Testing for a unit root in time series regression. Biometrika, 75: 335-436.

Reynolds, A. 2000. Monetary Policy by Trial and Error. In The Supply-Side Revolution: 20 Years Later. Joint Economic Committee, Washington. Retrieved from: http://www.senate.gov/_jec/ssreport1.htm.

Shapiro, M. and M.W. Watson, 1988. Sources of business cycle fluctuations. NBER Macroecon. Ann., 3: 111-156.

Sims, C.A., 1980. Macroeconomics and reality. Econometrica, 48(1): 1-48.

Suleman, D., S.K.A. Wasti, I. Lai and A. Hussain, 2009. An empirical investigation between money supply government expenditure, output and prices: The Pakistan evidence. Eur. J. Econ. Financ. Admin. Sci., 17: 60-68.

Weeks, 1999. Argued that about the role of fiscal policy in stimulating growth with critics arguing for a more expansionary fiscal stance to boost the long run growth rate of the economy. 